\title{
Correlation of Transvaginal USG and Endometrial aspiration findings with various menstruation patterns and histopathological examination of Uterus
}

\author{
Sharma B. ${ }^{1}$, Pavika Lal ${ }^{2}$, Singh S. ${ }^{3}$, Ranjan R. ${ }^{4}$ \\ ${ }^{1}$ Dr. Bandana Sharma, Professor, Department of Obstetrics \& Gynecology, Career Medical College, Lucknow, \\ ${ }^{2}$ Dr. Pavika Lal, Assistant Professor, Department of Obstetrics \& Gynecology, GSVM Medical College, Kanpur, \\ ${ }^{3}$ Dr. Sapna Singh, Professor, Department of Obstetrics \& Gynecology, Rama Medical College Mandhana, Kanpur, \\ ${ }^{4}$ Dr. Rahul Ranjan, Associate Professor, Department of Radio Diagnosis, Rama Medical College, Mandhana, Kanpur, \\ India.
}

Corresponding Author: Dr. Sapna Singh, Professor, Department of Obstetrics \& Gynecology, Rama Medical College Mandhana, Kanpur, India. E-mail: sapnasingh.305@gmail.com

\begin{abstract}
Background: Abnormal uterine bleeding (AUB) may be acute or chronic and is defined as bleeding from the uterine corpus that is abnormal in regularity, volume, frequency or duration and occurs in absence of pregnancy and it is a common manifestation of both benign \& malignant diseases of the uterus. Material \& Methods: This was a prospective study carried out in the department of Obstetrics \& Gynecology, Rama Medical College, Mandhana Kanpur during the three-year period from July 2014 July 2017. A total of 106 patients who were willing to participate in the study and had given consent for endometrial aspiration followed by hysterectomy were enrolled for the study. Data were recorded with respect to sociodemographic characteristics, clinical ultrasound and histopathological findings of the study population. Result: Majority of cases of AUB were diagnosed with adenomyosis followed by fibroid. Though ultrasound diagnosis of adenomyosis and fibroid were missed in some cases but the endometrial aspiration correlated well with the histopathological findings on hysterectomized specimen. Conclusion: Every woman presenting with AUB more than 40 Years must undergo endometrial aspiration assessment prior to hysterectomy to rule out any underlying malignancy and every hysterectomy specimen should be sent for final histopathological diagnosis as it is necessary for confirmation of the diagnosis as well as proper management and counseling of the patients.
\end{abstract}

Keywords: AUB (abnormal uterine bleeding), hysterectomy, Endometrial aspiration, Ultrasound, histopathology

\section{Introduction}

Abnormal uterine bleeding (AUB) may be acute or chronic and is defined as bleeding from the uterine corpus that is abnormal in regularity, volume, frequency or duration and occurs in absence of pregnancy [1,2]. It is a clinical presentation of benign or malignant lesions of female genital tract and not a disease and accounts for more than $70 \%$ of all gynecological consultations in the peri and post-menopausal age group [3]. The terminologies like menorrhagia, polymenorrhea, polymenorrhagia, metrorrhagia and menometrorrhagia should be abandoned because of their controversial, confusion and poorly defined usage according to extensive international discussions and have been replaced by new definitions [4-6].

AUB can be due to innumerable causes in this perimenopausal age group and therefore the etiology have been grouped under the acronym PALM COIN as described by FIGO.

The present study was carried out with the aim

a. To evaluate the various types of clinical presentations of AUB in peri and post menopausal age group.

Manuscript received: $10^{\text {th }}$ Jannuary 2019

Reviewed: $20^{\text {th }}$ January 2019

Author Corrected: $25^{\text {th }}$ January 2019

Accepted for Publication: $30^{\text {th }}$ January 2019

Obsgyne Review: Journal of Obstetrics and Gynecology

Available online at: www.medresearch.in $71 \mid \mathrm{P}$ a g e 


\section{Original Research Article}

b. To know the prevalence of the most common cause of AUB at our tertiary care centre.

c. To correlate the clinical, transvaginal ultrasound (USG) \& endometrial aspiration (EA) findings with the final histopathological reports of hysterectomy specimen.

Recommended Terminology, Definitions, and Classifications of Symptoms of Abnormal Uterine Bleeding [7]

\begin{tabular}{|c|c|}
\hline Disturbances in Regularity & Disturbances in Frequency \\
\hline $\begin{array}{l}\text { 1. Irregular menstrual bleeding (IrregMB): } \\
>20 \text { days in individual cycle lengths over a } \\
\text { period of } 1 \text { year }\end{array}$ & $\begin{array}{l}\text { 1.Infrequentmenstrualbleeding(oligomenorrhea): } \\
\text { One or two episodes in a } 90 \text {-day period. }\end{array}$ \\
\hline $\begin{array}{l}\text { 2. Absent menstrual bleeding (amenorrhea): } \\
\text { No bleeding in a } 90 \text {-day period }\end{array}$ & $\begin{array}{l}\text { 2.Frequent menstrual bleeding: More than } 3 \text { four } \\
\text { episodes in a } 90 \text {-day period }\end{array}$ \\
\hline Disturbances of Heaviness of Flow & Disturbances of the Duration of Flow \\
\hline $\begin{array}{l}\text { 1. Heavy menstrual bleeding (HMB): 'HMBshould } \\
\text { be defined as excessive menstrualblood loss which } \\
\text { interferes with thewoman's physical, emotional, social } \\
\text { and material quality of life, and which can occur alone } \\
\text { or in combination with other symptoms. }\end{array}$ & $\begin{array}{l}\text { 1.Prolonged menstrual bleeding: menstrual } \\
\text { periods that exceed } 8 \text { days in durationon a regular } \\
\text { basis and is commonly associated with heavy } \\
\text { menstrual bleeding("heavy and prolonged } \\
\text { menstrualbleeding"' [HPMB]). }\end{array}$ \\
\hline $\begin{array}{l}\text { 2. Heavy and prolonged menstrual bleeding } \\
\text { (HPMB): Less common than HMB. }\end{array}$ & $\begin{array}{l}\text { 2. Shortened menstrual bleeding: } \\
\text { menstrual bleeding of no longer than } 2 \text { days in } \\
\text { duration which is usually light in volume and is } \\
\text { uncommonly associatedwith serious pathology } \\
\text { (such asintrauterine adhesions and endometrial } \\
\text { tuberculosis). }\end{array}$ \\
\hline $\begin{array}{l}\text { 3. Light menstrual bleeding: Rarely related to } \\
\text { pathology and is cultural complaint in communities } \\
\text { where a heavy, "red" bleed is valued as a perceived } \\
\text { sign of health. }\end{array}$ & \\
\hline
\end{tabular}

\section{Materials \& Methods}

This was a prospective observational study carried out in the department of Obstetrics \& Gynecology, Rama Medical College, Mandhana Kanpur over a time period of 3 years duration from July 2014 to July 2017.

All the cases that presented with abnormal uterine bleeding \& had given consent for endometrial aspiration followed by hysterectomy above the age of 40 years were reviewed for the important details pertaining to the study.

Data were recorded with respect to their age, parity, clinical presentation with USG findings. All these females underwent endometrial aspiration \&followed by which these patients underwent hysterectomy by abdominal or vaginal route tissue and the tissue was sent to the pathology department for examination.
Histopathological reports of the hysterectomy specimens were co-related with USG \& EA findings.

\section{Inclusion criteria}

- Patients $>40$ years with AUB.

- Patients willing to undergo endometrial aspiration followed by hysterectomy if indicated.

- Patients willing to participate in the study

Exclusion criteria of patients willing to participate in the study-

- Patients with medical disorders

- Patient $<40$ years

- Patients with coagulopathy

- Patients who did not give consent for the study

\section{Results}

Majority of the patients who presented with AUB were in the age group of 40-50 yrs with parity of $\geq 3$ (Table1). Majority of the patients had HMB/HMPB accounting for $68.80 \% .92 .45 \%$ of patients presented with heavy menstrual bleeding with duration of 3-6 months reflecting that AUB is a major concern to them as it hinders with their day to day activities and make them prone to anemia and its ill effects (Table 2). 


\section{Original Research Article}

Majority of the patients who presented with HMB \& HPMB had adenomyosis and fibroid respectively while out of 11 patients who had post menopausal bleeding, only 2 patients had endometrial cancer as the primary diagnosis (Table $3 \&$ Table 4) On transabdominal USG, 35 (33.0\%) cases were diagnosed as adenomyosis, $28(26.49 \%)$ cases had bulky uterus followed by 25 cases of fibroid uterus (Table 3). In the remaining 18 cases, the basic pathology was related to the endometrial lining of uterus i.e. 13 cases had thickened endometrium, 3 hadendometrial polyp and 2 cases were diagnosed as carcinoma endometrium.

Table-1: Characteristics of the study population [Age (years) and Parity]

\begin{tabular}{|c|c|c|c|c|}
\hline Parity & $\mathbf{4 0 - 5 0}$ years & $\mathbf{5 1 - 6 0}$ years & >60 years & Total (\%) \\
\hline 0 & 0 & 2 & 0 & $2(1.88 \%)$ \\
\hline 1 & 3 & 4 & 0 & $7(6.60 \%)$ \\
\hline 2 & 13 & 5 & 6 & $24(22.64 \%)$ \\
\hline$\geq 3$ & 60 & 10 & 3 & $73(68.86 \%)$ \\
\hline Total & $\mathbf{7 6}(\mathbf{7 1 . 6 9 \% )}$ & $\mathbf{2 1}(\mathbf{1 9 . 8 1 \% )}$ & $\mathbf{9 ( 8 . 4 9 \% )}$ & $\mathbf{1 0 6}$ \\
\hline
\end{tabular}

Table-2: Distribution of menstrual complaints \& their duration (106 patients)

\begin{tabular}{|c|c|c|c|c|c|}
\hline \multirow{2}{*}{ Complaints } & \multirow{2}{*}{ No. of Patients } & \multicolumn{3}{|c|}{ Duration (in Months) } & \multirow{2}{*}{ Total } \\
\cline { 3 - 6 } & & $\leq \mathbf{3}$ Months & 3-6 Months & $\mathbf{6 - 1 2}$ Months & \\
\hline HMB & 43 & 14 & 26 & 3 & $43(40.50 \%)$ \\
\hline IMB & 22 & 3 & 15 & 4 & $22(20.75 \%)$ \\
\hline HPMB & 30 & 19 & 10 & 1 & $30(28.30 \%)$ \\
\hline PMB & 11 & 9 & 2 & 0 & $11(10.37 \%)$ \\
\hline Total & 106 & $45(42.45 \%)$ & $53(50 \%)$ & $8(7.54 \%)$ & 106 \\
\hline
\end{tabular}

Table-3: Co-relation of various menstrual bleeding patterns with USG findings

\begin{tabular}{|c|c|c|c|c|}
\hline USG Findings & HMB & IMB & PMB & HPMB \\
\hline Fibroid Uterus(25) & 8 & 2 & - & 15 \\
\hline Bulky Uterus (28) & 7 & 15 & - & 6 \\
\hline Adenomyosis (35) & 28 & 5 & - & 2 \\
\hline Thickened Endometrium (13) & - & - & 7 & 6 \\
\hline Endomatrial Polyp (3) & - & - & 2 & 1 \\
\hline Malignancy (2) & - & - & 2 & - \\
\hline Total (106) & $43(40.56 \%)$ & $22(20.75 \%)$ & $11(10.37 \%)$ & $30(28.30 \%)$ \\
\hline
\end{tabular}

Table-4: Correlation of USG diagnosis with histopathological examination (HPE) on hysterectomy specimen

\begin{tabular}{|l|c|c|c|c|}
\hline \multicolumn{1}{|c|}{ Diagnosis } & \multicolumn{2}{c|}{ USG } & \multicolumn{2}{c|}{ HPE } \\
\hline & No. of patients & Percentage & No. of patients & Percentage \\
\hline Fibroid & 25 & $23.58 \%$ & 29 & $27.35 \%$ \\
\hline Adenomyosis & 35 & $33.01 \%$ & 38 & $35.84 \%$ \\
\hline Bulky Uterus & 28 & $26.4 \%$ & 21 & $19.8 \%$ \\
\hline Endometrial Polyp & 3 & $2.83 \%$ & 3 & $2.83 \%$ \\
\hline Malignancy & 2 & $1.8 \%$ & 2 & $1.8 \%$ \\
\hline Thickened Endometrium & 13 & $12.26 \%$ & 13 & $12.26 \%$ \\
\hline Total & $\mathbf{1 0 6}$ & & $\mathbf{1 0 6}$ & \\
\hline
\end{tabular}

Histopathological report of myometrium revealed 38 cases of adenomyosis \& 29 cases of fibroid against USG diagnosis of $35 \& 25$ cases respectively. USG diagnosis of endometrial pathology exactly correlated in all 18 cases (Table 4). Out of 28 cases which were diagnosed as bulky uterus \& clinically as dysfunctional uterine bleeding, 4 cases were fibroid \& 3 cases were adenomyosis on final histopathological examination of the myometrium (Table 4). 
Original Research Article

Table-5:-Correlation of Endometrial aspiration report with histopathological findings on hysterectomy specimen

\begin{tabular}{|l|c|c|c|c|}
\hline \multirow{2}{*}{ Histopathology } & \multicolumn{2}{|c|}{ Endometrial Aspiration } & \multicolumn{2}{c|}{ Histopathological Examination } \\
\cline { 2 - 5 } & No. of Patients & Percentage & No. Of Patients & Percentage \\
\hline Proliferative Phase & 31 & $29.25 \%$ & 33 & $31.13 \%$ \\
\hline Secretory & 21 & $19.81 \%$ & 21 & $19.81 \%$ \\
\hline Simple Hyperplasia & 33 & $31.13 \%$ & 33 & $31.13 \%$ \\
\hline Complex Hyperplasia & 76 & $5.66 \%$ & 76 & $5.6 \%$ \\
\hline Endometrial Polyp & 2 & $1.88 \%$ & 3 & $6.83 \%$ \\
\hline Atrophic & 5 & $4.72 \%$ & 7 & $2.83 \%$ \\
\hline Carcinoma Endometrium & 2 & $1.88 \%$ & 3 & 106 \\
\hline
\end{tabular}

Table 5 shows the comparison of EA with the final histopathological diagnosis of endometrial disease and was found to be accurate in 100 cases $(94.33 \%)$ in our study. Majority of the patients who presented with HMB \& HPMB had proliferative endometrium followed by simple hyperplasia. Only 2 were the cases of endometrial carcinoma out of 11 patients with PMB.
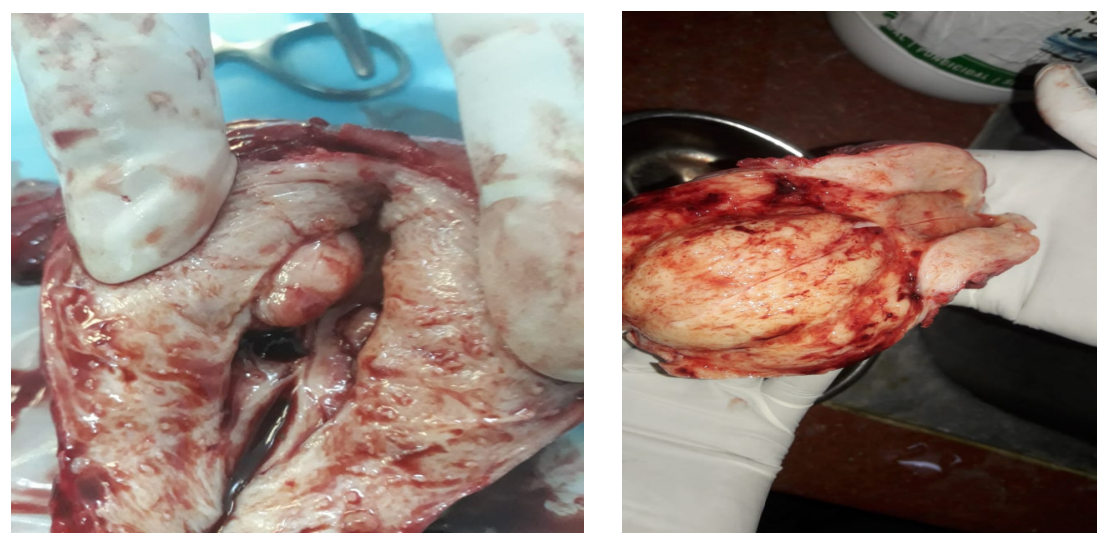

Figure-1: Uterine polyp with endometrial hyperplasiaFigure-2: Uterine fibroid

\section{Discussion}

AUB is the term used to describe deviation from a normal menstrual cycle and exhibit considerable variability manifesting with a wide range of bleeding patterns (HMB, HPMB, IMB) and is one of the main gynecological reasons of OPD visits and accounting for $2 / 3^{\text {rd }}$ of all hysterectomies [8]. Majority of the patients in our study belonged to $40-50$ years group with parity of $\geq 3$ and similar findings were observed by various studies $[9,10]$.

The incidence of AUB in this age group is due to increase number of anovulatory cycles signaling the climacteric phase of the menopausal period. The most common presenting symptom was HMB with the average duration ranging from 3-6 months in our study and was in concordance with the studies conducted by Jetley et al and Shobha et al $[11,12]$.
Only $7.54 \%$ of patients presented after 6 months of suffering from AUB \& majority seek medical advice within 6 months which was comparable to the study conducted by Talukdar et al and Kathuria et al [10,13]. This finding reflects the concern of this grave symptom in peri and post-menopausal age group along with the significant morbidity for which the patients seek early medical advice.

In our study, patients who had HMB \& HPMB were usually diagnosed as fibroid \& adenomyosis whereas patients presenting with IMB was diagnosed as dysfunctional uterine bleeding. Out of 106 hysterectomy specimens, 38 \& 29 were diagnosed as adenomyosis \& fibroid respectively in perimenopausal age group which was in concordance with the other studies [14-17]. 


\section{Original Research Article}

This may be because, fibroid \& adenomyosis are probably most common gynecological diseases in perimenopausal age group and also the commonest causes for which the patients undergo hysterectomy.

Transvaginal USG correlated accurately with the histopathological examination in all 18 cases of endometrial pathology like polyp, malignancy and thickened endometrium but missed out three and four cases of adenomyosis and fibroid respectively which were misdiagnosed as bulky uterus. Even the various studies conducted by Seidler et, Ascher et al, Reinhold et al. transabdominal or transvaginal USG does not allow a reliable diagnosis of adenomyosis or small fibroid because of limitations in tissue characterization $[18,19,20]$.

TVS measurement of endometrial thickness showed better discrimination between normal and pathological (hyperplasia/ malignancy) endometrium than any Doppler variable [21]. Anjali et al, in her study concluded that TVS could detect endometrial changes and can be well correlated with histopathology in $92 \%$ cases [22].

In the present study the most common finding on endometrial aspiration was normal cyclical pattern $(49.06 \%)$ out of which $31.13 \%$ showing proliferative endometrium and the rest $19.81 \%$ showing secretory endometrium. Endometrial aspiration was accurate in $94.33 \%$ of cases when compared to final histopathological examination.

The next predominant pattern was simple hyperplasia (31.13\%) which was more commonly found in perimenopausal age group. Atrophic and carcinoma endometrium remained confined to postmenopausal age group and similar histological patterns of the endometrium were reported by Shukla et al [9].

\section{Conclusion}

Our study was done with the intention to find out the most common cause of AUB in perimenopausal age group at our centre which caters to a large rural and urban areas of Kanpur was fibroid and adenomyosis.

Since the endometrial aspiration correlates well with the histopathological report of the hysterectomy specimens, every woman presenting with AUB $>40$ Years must undergo EA assessment prior to hysterectomy to rule out any underlying malignancy as it is a very cost effective procedure providing high diagnostic yield.
Also, every hysterectomy specimen should be sent for final histopathological diagnosis regardless of the endometrial sampling as it is of prime importance for confirmation of the diagnosis and for the optimal management and counseling of the patients.

Funding: Nil, Conflict of interest: Nil

Permission from IRB: Yes

\section{References}

1. Munro MG, Critchley HO, Broder MS, et al. FIGO classification system (PALM-COEIN) for causes of abnormal uterine bleeding in nongravid women of reproductive age. Int J Gynaecol Obstet. 2011 Apr;113 (1):3-13. doi: 10.1016/j.ijgo.2010.11.011. Epub 2011 Feb 22 .

2.Diagnosis of abnormal uterine bleeding in reproductive- aged women. Practice Bulletin No. 128. American College of Obstetricians and Gynecologists. Obstet Gynecol2012;120:197-206.

3. Mahajan N, Aggarwal M, Bagga A. Health issues of menopausal women in North India. $J$ Midlife Health. 2012 Jul; 3(2):84-7. doi: 10.4103/0976-7800. 104467.

4. Fraser IS, Critchley HO, Munro MG, et al. A process designed to lead to international agreement on terminologies and definitions used to describe abnormalities of menstrual bleeding. FertilSteril. 2007 Mar;87 (3):466-76. OI:10.1016/j.fertnstert.2007.01.023

5. Fraser IS, Critchley HO, Munro MG, et al. Can we achieve international agreement on terminologies and definitions used to describe abnormalities of menstrual bleeding? Hum Reprod. 2007 Mar;22(3):635-43. Epub 2007 Jan 4.DOI:10.1093/humrep/del478

6. Woolcock JG, Critchley HO, Munro MG, et al. Review of the confusion in current and historical terminology and definitions for disturbances of menstrual bleeding. FertilSteril. 2008 Dec;90 (6):226980. doi: 10.1016/j.fertnstert.2007.10.060. Epub 2008 Feb 6.

7. The FIGO Recommendations on Terminologies and Definitions for Normal and Abnormal Uterine Bleeding. Ian S. Fraser, Hilary O.D. Critchley, Michael Broder, and Malcolm G. Munro. Seminars in Reproductive Medicine 2011;29(5): 383-390

8. Telner DE, Jakubovicz D. Approach to diagnosis and management of abnormal uterine bleeding. Can Fam Physician. 2007 Jan;53(1):58-64. 


\section{Original Research Article}

9. Shukla Mansi, Fonscea Michelle, Kharat Deepali, Tekale Pallavi. A study to correlate histopathological findings in patients with AUB. Int. J Repot Contracept obstetgynaecol 2017 Feb; 6(2): 654-57

10. Talukdar Bharat Mahela Sangita AUB in perimenopausal women: correlation with sonographic findings and histopathological examination of hysterectomy specimens. J Mid life health 2016;7:73-7

11. Jetley S, Rana S, Jairajpuri ZS. Morphological spectrum of endometrial pathology in middle-aged women with atypical uterine bleeding: A study of 219 cases. J Midlife Health. 2013 Oct; 4 (4): 216-20. doi: 10.4103/0976-7800.122242.

12. Shobha PS. Sonographic and histopathological correlation and evaluation of endometrium in perimenopausal women with abnormal uterine bleeding. Int J Reprod Contracept ObstetGynaecol2014;3:113-7

13. KathuriaR, Bhatnagar B. Correlation between D \& $\mathrm{C}$, USG and hysterectomy findings in diagnosing a cause for abnormal uterine bleeding. Indian $\mathrm{J}$ Clin pract $2014 ; 25: 466-70$

14. Kumar V, Abbass AK, Aster CJ. Female genital tract. In: Robin's pathological basis of diseases. 9th ed. Philadelphia: WB Saunders 2013; p.628-704.

15. Gupta G, Kotasthane DS, Kotasthane VD. Hysterectomy: A Clinico-pathological Correlation of 500 cases. The Internet Journal of Gynaecology and Obstetrics 2010; 14(1).
16. Khan R, Sultana H. How does histopathology correlate with clinical and operative findings in abdominal hysterectomy?. JAFMC Bangladesh. 2010 Dec; 6(2):17 20.

17. Bhide P, Bhide A. Uterine Adenomyosis. J Obstet Gynecol. 1994; 44(4):612-5.

18. Siedler D, Laing FC, Jeffrey RB Jr, et al. Uterine adenomyosis. A difficult sonographic diagnosis. J Ultrasound Med. 1987 Jul;6 (7):345-9.

19. Ascher SM, Arnold LL, Patt RH, et al. Adenomyosis: prospective comparison of MR imaging and transvaginal sonography. Radiology. 1994 Mar;190 (3): 803-6.

20. Reinhold C, Atri M, Melino A, et al. Diffuse uterine adenomyosis; Morphologic criteria \& diagnostic accuracy of endovaginal sonography. Radiology, 1995; 197; 609-14.

21. Sladkevicius P, Valenten L, Marsal K. Endometrial thickness and Doppler velocimetry of the uterine arteries as discriminator of endometrial status in women with postmenopausal bleeding. A comprehensive study. Am J Obstet Gynecol. 1994;171:722-8

22. Singh A, Singh S, Mathur V, Singh K. Transvaginal sonography in dysfunctional uterine bleeding and its correlation with histopathology. J obstetGyunecol of India. 2005;51(6): 116-9

\section{How to cite this article?}

Sharma B., Pavika Lal, Singh S., Ranjan R. Correlation of Transvaginal USG and Endometrial aspiration findings with various menstruation patterns and histopathological examination of Uterus. Obs Rev: J obstet Gynecol 2019;5 (1): 7176.doi:10.17511/joog.2019.i01.13. 